\title{
Karakteristik Morfometrik Lamun Enhalus acoroides dan Thalassia hemprichii di Pesisir Pulau Bintan
}

\author{
Pratiwi Sarinawaty, Fadhliyah Idris, Aditya Hikmat Nugraha* \\ Program Studi IImu Kelautan, Fakultas IImu Kelautan dan Perikanan, Universitas Maritim Raja Ali Haji \\ Jl. Politeknik, Tanjungpinang 29111 Indonesia \\ ${ }^{*}$ Corresponding author, e-mail : adityahn@umrah.ac.id
}

\begin{abstract}
ABSTRAK: Lamun merupakan satu-satunya tumbuhan berbiji (angiospermae) yang mampu hidup terendam di dalam air laut dan beradaptasi pada lingkungan dengan salinitas tinggi serta memiliki rhizome, daun dan akar sejati. Kajian terkait karakteristik morfometrik menekankan pada keadaan karakter morfologi suatau spesies yang mendiami suatu wilayah tertentu. Penelitian ini dilakukan dengan tujuan untuk membandingkan karakteristik morfometrik lamun Enhalus acoroides dan Thalassia hemprichii pada ekosistem lamun di beberapa wilayah pesisir di Pulau Bintan. Penentuan lokasi penelitian ditentukan dengan metode purposive sampling sedangkan pengambilan data lamun menggunakan transek kuadran ukuran 50x50cm. Karakteristik bagian lamun yang diukur yaitu panjang daun, lebar daun, diameter rhizome, panjang akar dan jumlah daun. Karakteristik morfometrik lamun di ketiga lokasi memiliki perbedaan. Lamun E. acoroides di lokasi Pantai Impian memiliki panjang daun yang terpanjang dan diameter rhizome yang paling besar dari lokasi lainnya. Sedangkan lokasi pengudang memiliki lebar daun tertinggi. Morfometrik Lamun jenis $\mathrm{T}$. hemprichii yang mempunyai nilai panjang daun, lebar daun dan diameter rhizome tertinggi terdapat di lokasi Pantai Impian. Sedangkan panjang daun terendah terdapat di Pengudang.
\end{abstract}

Kata kunci: Bintan; Enhalus acoroides; Lamun; Morfometrik; Thalassia hemprichii

\section{Morphometric Characteristics of Seagrass Enhalus acoroides and Thalassia hemprichii in Coastal Areas on Bintan Island}

ABSTRACT: Seagrass is the only seed plant (angiosperms) that can live submerged in seawater and adapt to environments with high salinity and has rhizomes, leaves, and tree roots. Studies related to morphometric characteristics emphasize the morphological character of a species that inhabits a particular area. This research was conducted in October 2019 to March 2020 in Dompak, Pengudang Village, and Pantai Impian to compare the morphometric characteristics of the seagrass Enhalus acoroides and Thalassia hemprichii in seagrass ecosystems in some coastal areas of Bintan Island. The determination of the location of the study was determined by a purposive sampling method while seagrass data collection using a $50 \times 50 \mathrm{~cm}$ quadrant transect size. Morphometric characteristics of seagrasses in the three locations have differences. Seagrass E. acoroides at the Impian Beach location has the longest leaf length and the largest rhizome diameter than other locations. Whereas the storage location has the highest leaf width. Morphometrics of seagrass T. hemprichii which has the highest value of leaf length, leaf width, and rhizome diameter is at the Dream Beach location. While the lowest leaf length is found in Pengudang.

Keywords: Bintan; Enhalus acoroides; Morphometrics; Seagrass; Thalassia hemprichii

\section{PENDAHULUAN}

Lamun merupakan satu-satunya tumbuhan berbiji (angiospermae) yang mampu beradaptasi pada lingkungan dengan salinitas tinggi yang hidup terendam di dalam air laut serta memiliki rhizome, daun, dan akar sejati (Kawaroe et al. 2016). Hamparan lamun sebagai ekosistem utama pada suatu kawasan pesisir disebut sebagai padang lamun (seagrass bed). Dari sekitar 60 jenis lamun yang dikenal di dunia, Indonesia mempunyai sekitar 13 jenis (Hutomo dan Nontji 2014). 
Topografi pesisir Pulau Bintan yang landai dengan substrat berpasir dan berlumpur membuat lamun dapat tumbuh dengan baik (Nasution dan Siska 2012). Menurut penelitian yang dilakukan oleh Kawaroe et al. (2016), lamun yang ditemukan di perairan Bintan sebanyak 10 jenis diantaranya Thalassia hemprichii, Enhalus acoroides, Halophila ovalis, H. minor, H. spinulosa, Cymodocea rotundata, $C$. serrulata, Halodule uninervis, $H$. pinifolia, dan Syringodium isoetifolium.

Kajian terkait karakteristik morfometrik menekankan pada keadaan karakter morfologi suatau spesies yang mendiami suatu wilayah tertentu. Sebaran dan variasi morfometrik yang muncul merupakan respon terhadap lingkungan fisik tempat hidup spesies tersebut. Penelitian morfometrik merupakan salah satu kajian penting dalam bidang kelautan dan perikanan yang perlu dipublikasikan secara meluas. Hal ini dipandang penting karena variasi morfometrik suatu populasi pada kondisi geografi berbeda dapat disebabkan oleh perbedaan kondisi lingkungan (Tzeng et al. 2000).

Lamun E. acoroides dan T. hemprichii merupakan spesies kunci di Indo-Pasifik. Menurut Susetiono (2004) lamun jenis E. acoroides dan T. hemprichii merupakan jenis yang dominan di perairan Indonesia. E. acoroides tersebar luas sepanjang pesisir Samudera Hindia dan bagian tropis dari wilayah Pasifik bagian barat (Den Hartog dan Kuo 2006). Wilayah pesisir Pulau Bintan memiliki daerah sebaran lamun yang cukup luas dengan kondisi lingkungan perairan yang berbeda. Untuk itu perlu dilakukan penelitian tentang karakteristik morfometrik lamun $E$. acoroides dan T. hemprichii di pesisir Pulau Bintan.

\section{MATERI DAN METODE}

Penelitian ini dilakukan pada bulan Oktober 2019 hingga Maret 2020.Penelitian ini dilakukan di sebagian wilayah pesisir di Pulau Bintan tepatnya di Dompak, Pengudang dan Pantai Impian. Lokasi penelitian dapat dilihat pada Gambar 1.

Tutupan lamun merupakan persentase dari daun-daun lamun yang menutupi substrat dasar perairan yang dilihat dalam batasan transek kuadrat berukuran $50 \times 50 \mathrm{~cm}^{2}$, dengan posisi pengamat tegak lurus dengan transek (Rahmawati et al. 2014). Pengambilan data tutupan lamun dilapangan dilakukan dengan melihat nilai tutupannya berdasarkan persentase tutupan lamun dengan menghitung tutupan lamun dalam satu kuadrat dan persentase lamun per stasiun. Cara menghitung rata-rata penutupan lamun per stasiun adalah menjumlahkan penutupan lamun setiap kuadrat pada seluruh transek di dalam satu stasiun kemudian dibagi dalam jumlah kuadrat pada stasiun tersebut.

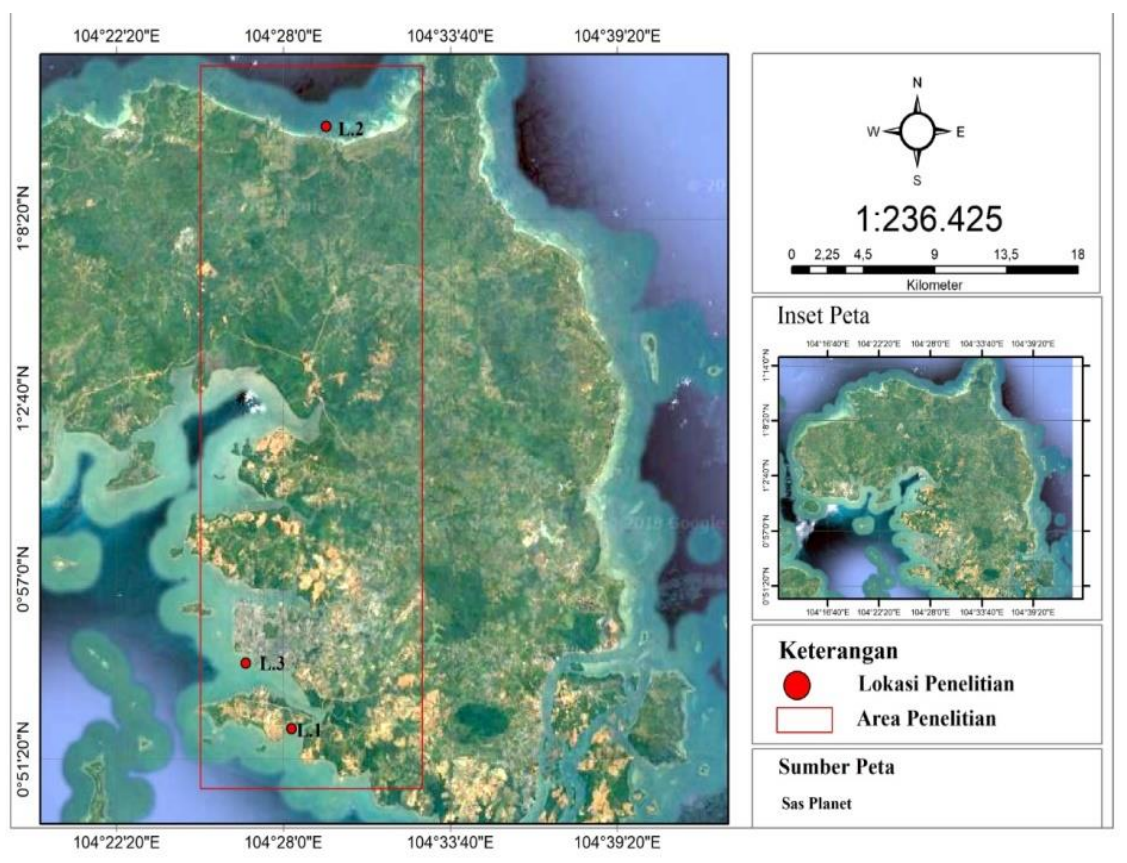

Gambar 1. Lokasi Penelitian di Pengudang, Dompak dan Pantai Impian 


\section{Pengambilan data Kerapatan Lamun}

Pengambilan data kerapatan lamun menggunakan teknik penghitungan dengan menggunakan transek berukuran $50 \mathrm{~cm} \times 50 \mathrm{~cm}$ diatas tutupan lamun tiap titiknya dan dilakukan tiga kali pengulangan.Pengambilan data kerapatan pada lamun dilakukan pada transek $30 \mathrm{~m}, 60 \mathrm{~m}$ dan $90 \mathrm{~m}$. Kerapatan lamun dihitung dengan cara menghitung jumlah tegakan lamun yang ada pada line transek yang mengarah ke arah laut sepanjang $100 \mathrm{~m}$.

\section{Pengambilan Sampel dan Pengukuran Karakteristik Morfometrik}

Pengambilan sampel morfometrik lamun dilakukan dengan menggali lamun sampai pada akarnya. Sampel langsung dikumpulkan lalu dicuci dengan air laut dan dimasukkan kedalam plastik sampel. Sampel kemudian diukur menggunakan penggaris dan jangka sorong. Karakteristik bagian lamun yang diukur yaitu panjang daun, lebar daun, diameter rhizome, panjang akar dan jumlah daun (Amale et al. 2016).

\section{Pengukuran Data Parameter Lingkungan Perairan}

Pengukuran parameter lingkungan antara lain, pengukuran parameter fisika yaitu Suhu dan Salinitas dan parameter kimia $\mathrm{pH}$, DO, Nitrat dan Fospat. Alat yang digunakan adalah Refraktometer dan Multitester. Nitrat dan posfat dilakukan uji di Labolatorium PT. Surveyor Batam.

\section{Pengambilan Sampel Sedimen}

Sampel sedimen diambil pada lokasi atau titik yang sudah ditentukan.Sampel sedimen diambil menggunakan sediment core yaitu pipa paralon yang dimasukkan kedalam substrat dasar. Kemudian sampel sedimen dimasukkan ke dalam plastik dan diberi label untuk kemudian dianalisis lebih lanjut di laboratorium.

\section{Analisis Data}

Tutupan lamun merupakan luasan area yang ditutupi oleh lamun dalam suatu unit area yang dihitung. Tutupan jenis lamun dapat dihitung dengan rumus berikut:

$$
\text { \%Tutupan Lamun }=\frac{\text { Jumlah Tutupan Lamun Seluruh Transek }}{\text { Jumlah Kuadrat Seluruh Transek }}
$$

Penilaian persentase tutupan lamun dikategorikan berdasarkan Tabel 1.

Tabel 1. Kategori tutupan lamun

\begin{tabular}{cc}
\hline Kategori & Nilai Tutupan Lamun (\%) \\
\hline $0-25$ & Jarang \\
$26-50$ & Sedang \\
$51-75$ & Padat \\
$76-100$ & Sangat Padat \\
\hline
\end{tabular}

Sumber: Rahmawati et al. (2014)

Kerapatan jenis lamun merupakan jumlah total individu suatu jenis lamundalam satu unit area yang dihitung. Kerapatan jenis lamun dihitung dengan rumus(Gosari dan Haris 2012).

\section{Analisis Fraksinasi Sedimen}

Analisis fraksi sedimen dilakukan untuk mendapatkan ukuran butir sedimensehingga diketahui jenis sedimennya. Metode yang digunakan dalam grain sizeyaitu dry sieving (pengayakan) menggunakan alat shieve shaker (Triapriyasen et al. 2016). Sampel sedimen yang masih basah dikeringkan terlebih dahulu dengan menggunakan oven dengan suhu $100{ }^{\circ} \mathrm{C}$, kemudian dilakukan pengayakan menggunakan shieve shaker dengan saringan berukuran 2,36mm; $2 \mathrm{~mm}$; 1,18 mm05; 0, $\mathrm{mm}$; dan 0,025 mm;0,125 mm;0,106mm. 


\section{PCA (Principal Component Analysis)}

Analisis Komponen Utama (PCA) adalah teknik yang digunakan untuk menyederhanakan suatu data, dengan cara mentransformasi linear sehingga terbentuk sistem koordinat baru dengan variansi maksimum. Digunakan untuk melihat keterkaitan antara parameter fisika kimia dengan parameter biologi. (Rizkifar et al. 2019).

\section{CA (correspondence Analysis)}

CA (Corespondence Analysis) bertujuan untuk mengelompokkan unit-unit statistik kedalam kelompok kelompok homogen dari sejumlah variabel. CA mengklasifikasikan objek sehingga objek yang serupa akan dikelompokkan dalam klaster yang sama, sesuai dengan kriteria yang digunakan (Radiarta dan Erlania, 2015). Proses pengolahan data dilakukan dengan menggunakan xlstat.

\section{HASIL DAN PEMBAHASAN}

Kondisi perairan di lingkungan ekosistem lamun dapat mempengaruhi kehidupan biota yang ada di perairan tersebut. Kondisi perairan yang diukur yaitu parameter fisika dan kimia meliputi suhu, salinitas, $\mathrm{pH}, \mathrm{DO}$, kekeruhan, nitrat, dan fosfat dengan hasil pengukuran seperti yang tertera pada Tabel 2.

Pengukuran suhu di tiga stasiun penelitian berkisar $31-32{ }^{\circ} \mathrm{C}$. Nilai tersebut lebih tinggi dari batas baku mutu pertumbuhan lamun yaitu $28-30{ }^{\circ} \mathrm{C}$. Kondisi tersebut dipengaruhi oleh cuaca yang cukup panas pada saat pengukuran di lapang karena pengambilan data dilakukan pada siang hari. Suhu dapat mempengaruhi proses fotosintesis. Apabila suhu berada diluar kisaran ambang batas maka kemampuan proses fotosintesis dapat menurun secara tajam (Poedjirahajoe et al. 2013).

Hasil pengukuran salinitas berkisar antara 30-32 \%. Baku mutu salinitas perairan lamun menurut KepMen LH No. 51 Tahun 2004 kisaran untuk pertumbuhan lamun berkisar 33-34 \%. Sebagian besar lamun memiliki toleransi terhadap salinitas yang lebar yaitu 10-40\% sehingga hasil pengukuran di setiap stasiun penelitian menunjukkan nilai salinitas masih dalam kisaran yang ditetapkan (Rugebregt, 2015).

Derajat keasaman $(\mathrm{pH})$ yang diperoleh di tiga lokasi penelitian termasuk normal dengan nilai berkisar 6.9-7.5. Nilai derajat keasaman di lokasi penelitian cenderung homogen atau seragam. $\mathrm{Hal}$ ini disebabkan $\mathrm{pH}$ air laut biasanya stabil dan tidak menunjukkan perubahan yang signifikan karena dalam air laut terdapat sistem karbonat (Nybakken 1992). Berdasarkan standar baku mutu, nilai $\mathrm{pH}$ di lokasi penelitian termasuk perairan yang produktif.

Pengukuran nilai oksigen terlarut (DO) di tiga lokasi penelitian berkisar antara 5.5-7.0 mg/L. Kandungan oksigen terlarut di suatu perairan berkaitan dengan respirasi oleh lamun, biota, dan pemakaian oleh bakteri nitrifikasi dalam proses siklus nitrogen di ekosistem padang lamun (Fahrudin et al. 2017). Menurut KepMen LH No. 51 Tahun 2004 Nilai DO di ketiga lokasi penelitian masih berada dalam jumlah yang cukup bagi pertumbuhan lamun.

Tabel 2. Parameter fisika kimia perairan

\begin{tabular}{lcccc}
\hline \multirow{2}{*}{ Parameter } & \multicolumn{3}{c}{ Stasiun } & \multirow{2}{*}{ Baku Mutu } \\
\cline { 2 - 4 } & Dompak & Pengudang & Pantai Impian & \\
\hline Suhu $\left({ }^{0} \mathrm{C}\right)$ & 31.000 & 31,800 & 32.000 & $28-30$ \\
Salinitas $(\%)$ & 31.000 & 30.00 & 32.000 & $33-34$ \\
$\mathrm{pH}$ & 7.500 & 6.990 & 7.100 & $7-8.5$ \\
DO $(\mathrm{mg} / \mathrm{L})$ & 5.500 & 7.000 & 6.200 & $>5$ \\
Nitrat $(\mathrm{mg} / \mathrm{L})$ & 0.003 & 0.008 & 0.005 & 0.008 \\
Fosfat $(\mathrm{mg} / \mathrm{L})$ & 0.007 & 0.006 & 0.007 & 0.015 \\
Kekeruhan $(\mathrm{NTU})$ & 1.420 & 0.420 & 2.280 & $<5$ \\
\hline
\end{tabular}


Hasil pengukuran nutrien pada lokasi penelitian berkisar antara $0.003-0.008$. Menurut KEPMEN LH (2004) menunjukkan bahwa kisaran nitrat yang baik bagi lamun adalah sebesar $0.008 \mathrm{mg} / \mathrm{L}$. Lokasi Pengudang memiliki nitrat yang baik bagi pertumbuhan lamun sedangkan lokasi Dompak dan Pantai Impian memiliki nilai yang agak rendah namun masih mendukung untuk pertumbuhan lamun. Nitrat merupakan bentuk utama nitrogen di perairan laut dan merupakan nutrien utama bagi pertumbuhan lamun.

Nilai fosfat di masing-masing lokasi memiliki kandungan yang hampir sama dan masih tergolong rendah tapi masih cukup untuk mendukung kehidupan lamun.Semakin menuju dasar maka konsentrasi fosfat akan semakin tinggi, hal ini diakibatkan kekayaan nutrisi yang ada di dasar laut (Souhoka dan Patty 2013). Kandungan nutrien yang rendah dipengaruhi oleh kurangnya masukan bahan organik ke perairan. Ketersedian zat hara (nutrien) diperairan padang lamun dapat berperan sebagai faktor pembatas pertumbuhannya (Zulkifli 2000).

Hasil rata-rata pengukuran kekeruhan pada lokasi penelitian berkisar0,42 - 2,28 NTU. Kekeruhan dipengaruhi oleh faktor substrat yang, pasang surut, arus, gelombang dan cuaca. Karena itu kekeruhan lebih tinggi di substrat lumpur. Kekeruhan yang tinggi akan mempengaruhi proses fotosintesis yang dilakukan oleh lamun karena intensitas cahaya yang masuk dalam kolom perairan akan di pantulkan kembali oleh partikel-partikel tersuspensi, sehingga secara langsung bisa mempengaruhi laju pertumbuhan lamun.Menurut KepMen LH No. 51 Tahun 2004 nilai kekeruhan masih termasuk kedalam perairan yang baik untuk pertumbuhan lamun.

\section{Karakteristik Sedimen}

Keberadaan sedimen sangat penting bagi lamun, sebagai tempat hidup dan pemasok nutrisi (Newmaster et al., 2011). Metekohy (2016) menyatakan bahwa lamun menyukai substrat berlumpur, berpasir, tanah liat ataupun substrat dengan patahan karang serta pada celah-celah batu. Persentase Fraksi Sedimen pada Lokasi Penelitian dapat dilihat pada Tabel 4. Hasil fraksi Sedimen pada tabel 4 menunjukkan pada lokasi penelitian Dompak dan Pantai Impian secara umum memiliki sedimen dasar laut yang dominan pasir dan lumpur, sedangkan Pengudang memiliki sedimen pasir dan kerikil. kelompok jenis pasir dan kerikil ditemukan pada bagian utara Pulau Bintan. Sedangkan kelompok sedimen jenis pasir dan lumpur ditemukan di daerah lokasi bagian barat Tanjungpinang.

\section{Tutupan Lamun Enhalus acoroides dan Thalassia hemprichii}

Tutupan lamun dipengaruhi oleh kerapatan lamun dan morfologi lamun terutama lebar daun. Karena semakin lebar daun lamunnya maka daerah substratnya akan semakin tertutupi. Penutupan lamun berkaitan dengan tingkat kesehatan dari ekosistem lamun di suatu perairan, semakin tinggi persen tutupannya maka tingkat kesehatan ekosistem lamun juga tinggi (Fahruddin et al. 2017). Hasil tutupan lamun E. acoroides dan T. Hemprichii dapat dilihat pada Gambar 2.

Hasil persentase tutupan lamun T. hemprichii pada lokasi Pantai Impian memiliki persentase tutupan yang paling tinggi dengan nilai tutupan $52.94 \%$ sedangkan $E$. acoroides memiliki tutupan sebesar $13.13 \%$. Lokasi pengudang mempunyai persentase $T$. hemprichii $24.49 \%$ dan $E$. acoroides $15.02 \%$. Lokasi dompak memiliki persentase tutupan lamun $T$. hemprichii $4.48 \%$ dan $E$. acoroides $15.06 \%$. Berdasarkan Rahmawati et al. (2014) tutupan lamun T. hemprichii pada lokasi Pantai Impian termasuk kategori padat, di lokasi pengudang termasuk kedalam kondisi sedang dan lokasi Dompak termasuk kedalam kondisi jarang. Tutupan E. acoroides di ketiga lokasi penelitian termasuk dalam kondisi yang jarang. Tutupan E. acoroides tertinggi ada di Pengudang dengan nilai tutupan $15.02 \%$. Nilai ini lebih kecil bila dibandingkan dengan penelitian pada lokasi lain, seperti pada di Pulau Talango, Madura yang memiliki tutupan lamun E. acoroides sebesar 30\% (Sukandar dan Dewi 2017). Menurut Tangke (2010) E. acoroides dominan hidup pada substrat dasar berpasir dan pasir sedikit berlumpur dan kadang-kadang terdapat pada dasar yang terdiri atas campuran pecahan karang yang telah mati. Beberapa faktor yang mempengaruhi tutupan lamun adalah kerapatan lamun dan pasang surut.

Berdasarkan persentase tutupan lamun pada Gambar 5 menunjukkan persen tutupan jenis lamun didominasi oleh jenis T.hemprichii. Hal ini dikarenakan lamun jenis $T$. hemprichii memiliki kerapatan jenis yang sangat tinggi dibandingkan lamun jenis $E$. acoroides. 
Tabel 3. Persentase Fraksi Sedimen pada masing-masing Lokasi Penelitian

\begin{tabular}{lcccc}
\hline \multirow{2}{*}{ Stasiun } & \multicolumn{3}{c}{ Fraksi sedimen } \\
\cline { 2 - 5 } & Kerikil & Pasir & Lumpur & Jenis sedimen \\
\hline Dompak & 2.23 & 87.54 & 10.09 & Pasir berlumpur \\
Pengudang & 6.54 & 90.35 & 2.09 & Pasir berkerikil \\
Pantai Impian & 1.27 & 79.94 & 18.69 & Pasir berlumpur \\
\hline
\end{tabular}

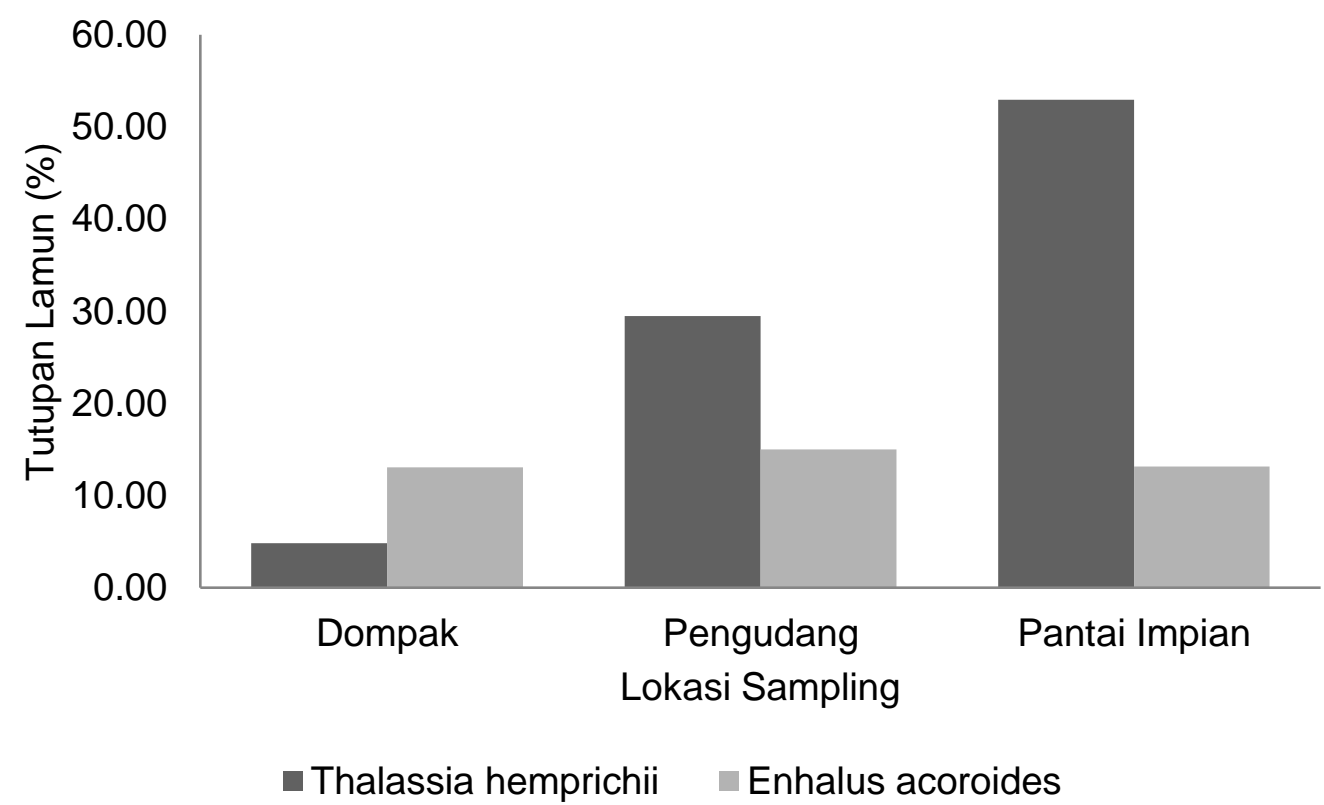

Gambar 2. Persen tutupan lamun jenis Enhalus acoroidesdan Thalassia hemprichii total pada masing-masing lokasi penelitian

\section{Kerapatan Jenis Enhalus acoroides dan Thalassia hemprichii}

Kerapatan spesies lamun adalah banyaknya jumlah individu/tegakan suatu spesies lamun pada luasan tertentu. Kerapatan lamun pada stasiun penelitian dapat dilihat pada Gambar 3. Kerapatan lamun yang tertinggi berada pada Lokasi Pantai Impian dengan kerapatan mencapai $306 \mathrm{ind} / \mathrm{m}^{2}$ kemudian di Lokasi Pengudang memiliki kerapatan sebesar $248 \mathrm{ind} / \mathrm{m}^{2}$ dan kerapatan terendah berada pada Lokasi Dompak dengan nilai sebesar $73 \mathrm{ind} / \mathrm{m}^{2}$. Hasil kerapatan lamun $T$. hemprichii pada lokasi Pantai Impian memiliki persentase kerapatan yang paling tinggi dengan nilai $270 \mathrm{ind} / \mathrm{m}^{2}$ sedangkan $E$. acoroides memiliki kerapatan sebesar $36 \mathrm{ind} / \mathrm{m}^{2}$. Lokasi pengudang mempunyai kerapatan $T$. hemprichii nilai $184 \mathrm{ind} / \mathrm{m}^{2}$ sedangkan $E$. acoroides $64 \mathrm{ind} / \mathrm{m}^{2}$. Lokasi Dompak memiliki kerapatan lamun $T$. hemprichii nilai $30 \mathrm{ind} / \mathrm{m}^{2}$ sedangkan $E$. acoroides memiliki kerapatan sebesar $43 \mathrm{ind} / \mathrm{m}^{2}$. Nilai kerapatan ini berbeda bila dibandingkan dengan lokasi penelitian yang lain. Seperti yang ditemukan di Pantai Teluk Bakau dimana lamun jenis $E$. acoroides memiliki kerapatan $46 \mathrm{ind} / \mathrm{m} 2$ di dan di Pulau Beralas Pasir T. hemprichii memiliki kerapatan $92 \mathrm{ind} / \mathrm{m}^{2}$ (Nugraha et al. 2019). Menurut Kiswara (2004), kerapatan jenis lamun di pengaruhi faktor tempat tumbuh dari lamun tersebut. Beberapa faktor yang mempengaruhi kerapatan jenis lamun di antaranya adalah kedalaman, kecerahan, arus air dan tipe substrat.

Tingginya kerapatan lamun $T$. hemprichii hampir mendominasi di setiap Lokasi penelitian. Hal tersebut dikarenakan lamun jenis ini biasanya hidup di area dengan substrat pasir hingga berlumpur (Kawaroe et al. 2016). Menurut Anggraini (2008) jenis lamun T. hemprichii paling banyak ditemukan berasosiasi dengan jenis lain dan tumbuh baik sampai kedalaman 25 meter. $E$. acoroides di tiga Lokasi penelitian rata-rata banyak ditemukan pada daerah yang dekat dengan pantai dan semakin ke arah laut jumlahnya semakin menurun. Hal ini dikarenakan semakin kearah laut jumlah nutrient semakin sedikit. 


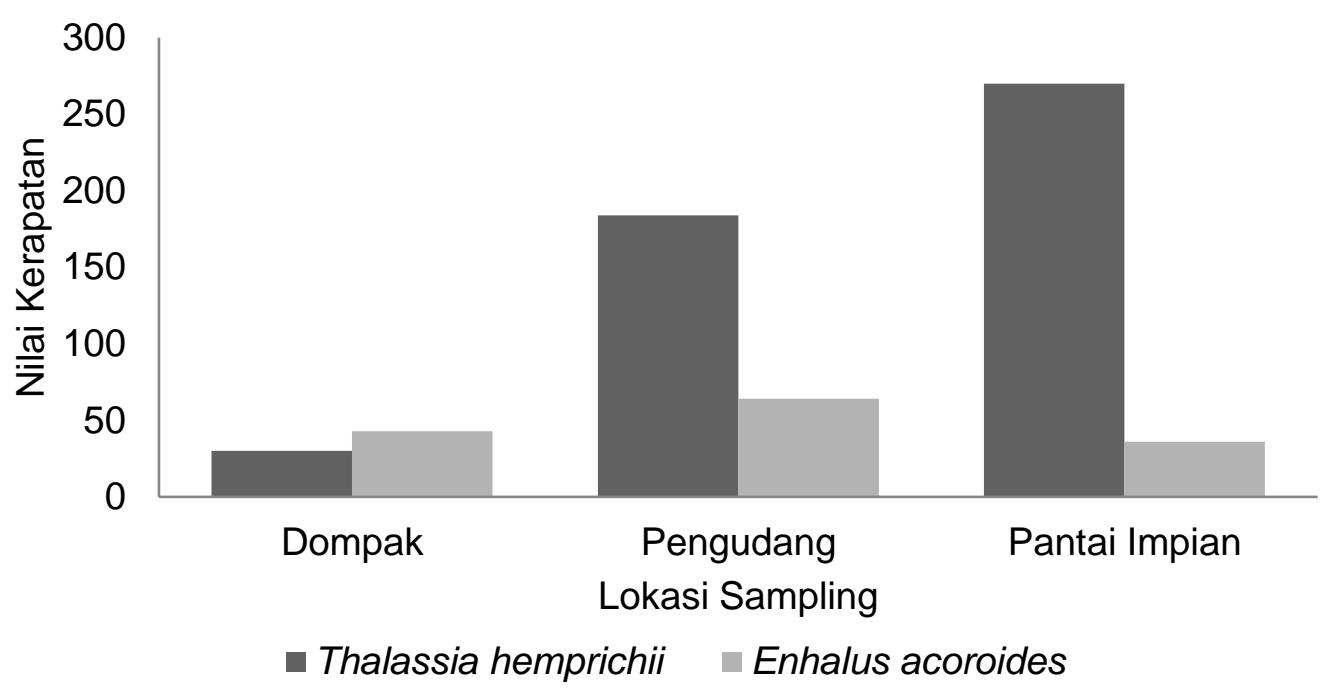

Gambar 3. Kerapatan lamun E. Acoroides dan T. hemprichii pada masing-masing lokasi penelitian

\section{Karakteristik Morfometrik Lamun}

Pengukuran morfometrik yang dilakukan dalam penelitian ini adalah $E$. acoroides dan $T$. hemprichii. Lamun jenis E. acoroides dan T. Hemprichii merupakan jenis yang dominan pada ketiga lokasi penelitian.Hasil pengukuran morfometrik pada lamun jenis $E$. acoroides dapat dilihat pada Tabel 4.

Panjang rata-rata daun lamun $E$. acoroides yang didapatkan dari pengukuran di tiga lokasi penelitian memiliki nilai yang bervariasi. Lokasi Pengudang memiliki rata-rata panjang daun paling rendah yaitu $32.38 \mathrm{~cm}$ dan diikuti Lokasi Dompak dengan panjang $42.48 \mathrm{~cm}$. Lokasi Pantai Impian memiliki rata-rata panjang daun paling tinggi dengan panjang $44.05 \mathrm{~cm}$. Hal ini disebabkan karena kedaan perairan pada lokasi Dompak dan Pantai Impian lebih tenang sehingga banyak mengendapkan sedimen, khususnya sedimen organik yang dibutuhkan untuk pertumbuhan lamun. Pada perairan tenang pertumbuhan lamun lebih terpusat pada panjang dan lebar daun sedangkan puncak dari helaian daun seringkali terkikis oleh energi gelombang dan keterbukaan terhadap pasang surut pada perairan yang relatif dangkal (Arifin 2001).

Hasil pengukuran rata-rata lebar daun menunjukkan bahwa di Lokasi Dompak memiliki hasil lebar daun $1.21 \mathrm{~cm}$ dan Lokasi Pantai Impian memiliki hasil $1.29 \mathrm{~cm}$. Hasil pengukuran rata-rata lebar daun terbesar terdapat pada Lokasi Pengudang dengan lebar rata-rata sebesar $1.39 \mathrm{~cm}$. Jika dibandingkan dengan penelitian lokasi lain yang dilakukan di Teluk Bakau dimana lamun pada substrat pasir memiliki rata-rata lebar daun sebesar 1.49. Hasil pengukuran diameter rhizome di setiap Lokasi Penelitian memiliki nilai rata-rata yang berbeda. Lokasi Dompak dan Pengudang memiliki diameter yang hampir sama yaitu 1.28 dan $1.27 \mathrm{~mm}$ sedangkan pada Lokasi Pantai Impian memiliki diameter yang lebih besar yaitu $1.41 \mathrm{~mm}$. Panjang akar $T$. hemprichii di ketiga stasiun pengamatan memiliki nilai rata-rata yang bervariasi. Panjang akar tertinggi diperoleh pada Lokasi Dompak dengan panjang $9.93 \mathrm{~cm}$, sedangkan Lokasi Pantai Impian memiliki panjang akar rata-rata sebesar $7.45 \mathrm{~cm}$. Lokasi Pengudang memiliki panjang akar rata-rata yang paling rendah yaitu $6.13 \mathrm{~cm}$. Fraksi sedimen juga memainkan peranan dalam sistem perakaran lamun, sebagai bahan perbandingan dengan lokasi lain menunjukkan bahwa setiap lokasi memiliki karakteristik morfometrik yang berbeda (Tabel 6). Morfometrik lamun di ketiga lokasi penelitian ini memiliki ukuran yang lebih kecil hasilnya jika dibandingkan dengan beberapa lokasi lain seperti yang ada pada Tabel 5.

Karakteristik morfologi lamun T.hemprichii disajikan pada Tabel 6. Panjang rata-rata daun lamun $T$. hemprichii yang didapatkan dari pengukuran di tiga lokasi penelitian memiliki nilai yang bervariasi. Lokasi Pantai Impian memiliki rata-rata daun paling panjang yaitu $14.26 \mathrm{~cm}$ dan diikuti Lokasi Dompak dengan panjang $10.28 \mathrm{~cm}$. Lokasi Pengudang memiliki rata-rata panjang daun paling rendah yaitu $7.03 \mathrm{~cm}$. Hasil pengukuran rata-rata lebar daun menunjukkan bahwa di lokasi Dompak dan lokasi Pengudang memiliki hasil yang hampir sama yaitu berkisar 0.89 dan $0.91 \mathrm{~cm}$. 
Hasil pengukuran rata-rata lebar daun terbesar terdapat pada lokasi Pantai Impian dengan lebar rata-rata sebesar $1.01 \mathrm{~cm}$. T. hemprichii yang berada di pulau yang sama juga memiliki morfometrik yang berbeda, seperti yang ada pada Teluk Bakau. Perbedaan Pengudang dan Teluk Bakau yaitu terlihat dari panjang daun dan lebar daun. Hasil pengukuran diameter rhizome di setiap Lokasi Penelitian memiliki nilai rata-rata yang berbeda. Lokasi Dompak dan Pengudang memiliki diameter yang hampir sama yaitu 0.23 dan $0.27 \mathrm{~mm}$ sedangkan pada lokasi Pantai Impian memiliki diameter yang lebih besar yaitu $0.38 \mathrm{~mm}$. Panjang akar $T$. hemprichii di ketiga stasiun pengamatan memiliki nilai rata-rata yang bervariasi.

Panjang akar tertinggi diperoleh pada lokasi Dompak dengan panjang $6.56 \mathrm{~cm}$, sedangkan lokasi Pengudang memiliki panjang akar rata-rata yang rendah yaitu $3.18 \mathrm{~cm}$. Lokasi Pantai Impian memiliki panjang akar rata-rata sebesar $3.07 \mathrm{~cm}$. Panjang akar yang tinggi disebabkan karena kondisi substrat di lokasi Dompak lebih halus sedangkan pada lokasi Pantai Impian memiliki substrat yang lebih kasar. Substrat dasar yang lebih halus memiliki kandungan nutrien yang lebih tinggi dibandingkan dengan substrat substrat kasar sehingga akar akan semakin panjang dan memudahkan dalam penyerapan nutrien (Rizal et al. 2017). Kondisi arus juga mempengaruhi panjang akar karena di lokasi Dompak memiliki arus yang tenang sehingga akar mudah dalam mengikat sedimen. Sebagai bahan perbandingan dengan lokasi lain menunjukkan bahwa setiap lokasi memiliki karakteristik morfometrik lamun E.acoroides yang berbeda (Tabel 6). Morfometrik pada lokasi penelitian ini memiliki ukuran morfometrik yang lebih kecil jika dibandingkan dengan beberapa lokasi lainnya seperti yang terdapat pada Tabel 7.

\section{Keterkaitan Kerapatan Lamun denganParameter Lingkungan Perairan}

Analisis keterkaitan parameter lingkungan perairan dengan kerapatan lamun dilakukan dengan menggunakan Principal Component Analysis (PCA). Parameter lingkungan perairan yang digunakan antara lain suhu, salinitas $\mathrm{pH}$, DO, Nitrat, Fospat, kekeruhan, lumpur, pasir dan kerikil. Hasil analisis disajikan pada Gambar 4.

Tabel 4. Morfometrik Lamun E. acoroides di lokasi Dompak, Pengudang dan Pantai Impian

\begin{tabular}{lccccc}
\hline Lokasi & Panjang Daun & Lebar Daun & Panjang Akar & Diameter Rhizome & Jumlah Daun \\
\hline Dompak & $42.48 \pm 15.20$ & $1.21 \pm 0.23$ & $9.93 \pm 3.62$ & $1.28 \pm 0.15$ & $4 \pm 1$ \\
Pengudang & $32.28 \pm 6.53$ & $1.39 \pm 0.15$ & $6.13 \pm 2.85$ & $1.27 \pm 0.16$ & $5 \pm 1$ \\
Pantai Impian & $44.05 \pm 13.36$ & $1.29 \pm 0.18$ & $7.45 \pm 3.48$ & $1.41 \pm 0.25$ & $4 \pm 1$ \\
\hline
\end{tabular}

Tabel 5. Karakteristik morfometrik lamun E.acoroides di lokasi lain

\begin{tabular}{lccccc}
\hline \multicolumn{1}{c}{ Lokasi } & $\begin{array}{c}\text { Panjang daun } \\
(\mathrm{cm})\end{array}$ & $\begin{array}{c}\text { Lebar daun } \\
(\mathrm{cm})\end{array}$ & $\begin{array}{c}\text { Panjang } \\
\text { akar }(\mathrm{cm})\end{array}$ & $\begin{array}{c}\text { Panjang rhizome } \\
(\mathrm{mm})\end{array}$ & Sumber \\
\hline $\begin{array}{l}\text { Kelurahan } \\
\text { Tongkeina }\end{array}$ & $2.0-54.3$ & $0.6-1.5$ & $1.0-27.0$ & $1.0-8$ & $\begin{array}{c}\text { Wagey dan } \\
\text { Sake (2013) }\end{array}$ \\
$\begin{array}{l}\text { Pulau Sarappo } \\
\text { Lompo }\end{array}$ & 52.9 & 1.39 & 18.7 & 5.7 & $\begin{array}{c}\text { Hasanuddin } \\
(2013)\end{array}$ \\
$\begin{array}{l}\text { Perairan } \\
\text { Tongkaina }\end{array}$ & $23.6-45.1$ & $1.0-1.1$ & $3.1-10.9$ & - & $\begin{array}{c}\text { Wangkanusa et } \\
\text { al. (2017) }\end{array}$ \\
\hline
\end{tabular}

Tabel 6. Morfometrik Lamun T. hemprichii di Dompak, Pengudang dan Pantai Impian

\begin{tabular}{lccccc}
\hline Lokasi & Panjang Daun & Lebar Daun & Panjang Akar & Diameter Rhizome & Jumlah Daun \\
\hline Dompak & $10.28 \pm 1,97$ & $0.89 \pm 0.22$ & $6.56 \pm 2.77$ & $0.23 \pm 0.12$ & $4 \pm 1$ \\
Pengudang & $7.03 \pm 1,45$ & $0.91 \pm 0.12$ & $3.18 \pm 1.12$ & $0.27 \pm 0.05$ & $5 \pm 1$ \\
Pantai Impian & $14.26 \pm 6,09$ & $1.01 \pm 0.16$ & $3.07 \pm 0.86$ & $0.38 \pm 0.29$ & $4 \pm 1$ \\
\hline
\end{tabular}


Tabel 7. Hasil pengukuran morfometrik lokasi lain

\begin{tabular}{lccccc}
\hline \multicolumn{1}{c}{ Lokasi } & $\begin{array}{c}\text { Panjang } \\
\text { daun }(\mathrm{cm})\end{array}$ & $\begin{array}{c}\text { Lebar daun } \\
(\mathrm{cm})\end{array}$ & $\begin{array}{c}\text { Panjang } \\
\text { akar }(\mathrm{cm})\end{array}$ & $\begin{array}{c}\text { Panjang rhizome } \\
(\mathrm{mm})\end{array}$ & Sumber \\
\hline Desa Bahoi & $3.2-7.8$ & $0.8-1.1$ & $2.8-8.0$ & $19.5-88.5$ & Kansil et al. (2019) \\
Kelurahan & $0.5-15.50$ & $0.3-1.1$ & $0.3-15.0$ & $8.0-60.0$ & Wagey dan Sake (2013) \\
$\begin{array}{l}\text { Tongkeina } \\
\text { Arakan }\end{array}$ & $5.7-12.1$ & $0.4-1.0$ & $2.8-12.8$ & $37.0-94.0$ & Sakey et al. (2015) \\
\hline
\end{tabular}

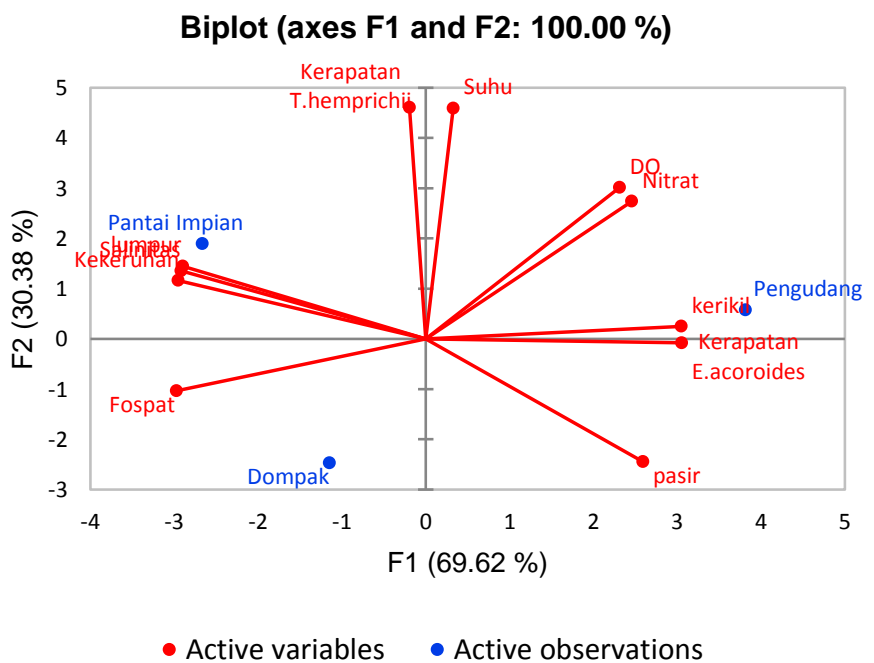

Gambar 4. Principal Component Analysis (PCA)

Hasil dari analisis komponen utama pada Gambar 4 menunjukkan pada sumbu (F1) memiliki nilai keragaman 30.38 \% dan keragaman pada sumbu F2 69.62\%. Lokasi Pantai Impian berada pada sumbu (F2) positif dicirikan oleh suhu, DO, nitrat dan kerapatan T. hemprichii. Menurut Handayani et al. (2016) nitrat merupakan unsur hara yang sangat dibutuhkan oleh tumbuhan untuk tumbuh dan sangat berpengaruh terhadap kandungan biomassa dan pertumbuhan lamun. Terlihat bahwa kerapatan T. hemprichii. memiiki korelasi positif dengan suhu. Seperti yang dikatakan Kadi (2006) bahwa suhu dapat mempengaruhi proses-proses fisiologis lamun seperti fotosintesis dan kerapatan. Pengudang berada pada sumbu (F1) positif dicirikan oleh pasir, kerikil dan kerapatan lamun E. acoroides. Dari hasil pada gambar 5 lamun jenis $E$. acoroides hidup lebih baik pada substrat yang memiliki karakteristik pasir dan kerikil. Sesuai dengan Tangke (2010) yang mengatakan bahwa $E$. acoroides dominan hidup pada substrat dasar berpasir.

\section{Sebaran Morfometrik Lamun Terhadap Masing-masing Lokasi}

Sebaran morfometrik lamun terhadap masing-masing lokasi didapatkan dengan menggunakan Correspondence Analysis (CA). Karakteristik bagian lamun yang digunakan yaitu panjang daun, lebar daun, diameter rhizome, panjang akar dan jumlah daun. Hasil Correspondence Analysis (CA) morfometrik lamun terhadap masing-masing lokasi penelitian dapat dilihat pada Gambar 5.

Hasil Correspondence Analysis (CA) yang ditunjukkan dari gambar diatas sumbu F1 memiliki kontribusi sebesar $69.92 \%$ dan sumbu F2 memiliki sebesar $30.68 \%$. Lokasi Dompak dicirikan oleh panjang akar E. acoroides dan T. hemprichii dan dipengaruhi oleh parameter salinitas, kekeruhan dan substrat lumpur. Substrat dasar yang lebih halus memiliki kandungan nutrien yang lebih tinggi dibandingkan dengan substrat kasar sehingga akar akan semakin panjang dan memudahkan dalam penyerapan nutrien (Rizal et al. 2017). Lokasi Pantai Impian dicirikan dengan panjang daun $T$. hemprichii dan E. acoroides yang dipengaruhi oleh fospat, sedangkan lokasi Pengudang dicirikan oleh diameter rhizome dan lebar daun E. acoroides dan T. hemprichii dan dipengaruhi oleh suhu, DO, nitrat dan kerikil. 
Symmetric plot

(axes F1 and F2: 100,00\%)

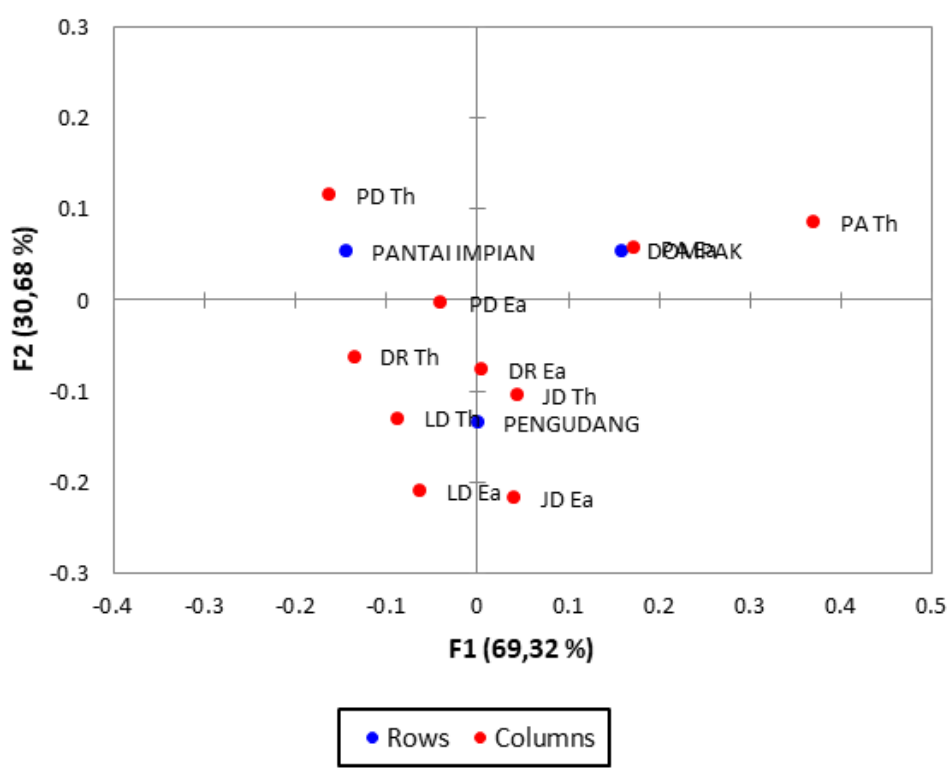

Gambar 5. Correspondence Analysis (CA)

\section{KESIMPULAN}

Karakteristik morfometrik di ketiga lokasi penelitian memiliki perbedaan. Panjang daun lamun Enhalus acoroides tertinggi terdapat di lokasi Pantai Impian. Lebar daun E. acoroides tertinggi terdapat pada lokasi Pengudang. Panjang akar terpanjang terdapat di lokasi Dompak. Diameter rhizome tertinggi terdapat pada Lokasi Pantai Impian. Jenis Thalassia hemprichii panjang daun tertinggi terdapat di lokasi Pantai Impian. Lebar daun tertinggi terdapat pada lokasi Pantai Impian. Panjang akar terpanjang terdapat di lokasi Dompak. Diameter rhizome tertinggi terdapat pada Lokasi Pantai Impian.

\section{DAFTAR PUSTAKA}

Amale, D., Kondoy, K.I.F., Rondonuwo, A.B. 2016. Struktur morfometrik lamunHalophila ovalis di Perairan Pantai Tongkaina Kecamatan Bunaken Kota. Jurnal IImu Platax. 4(2):67-75.

Anggraini, K. 2008. Mengenal Ekosistem Perairan. Jakarta. Grasindo

Fahruddin, M.F., Yulianda. \& Setyobudiandi, I. 2017. Kerapatan dan penututupan ekosistem lamun di Pesisir Desa Bahoi, Sulawesi Utara. Jurnal IImu dan Teknologi Kelautan Tropis. 9(1):375383.

Gosari., B.A.J. \& Haris, A. 2012. Studi kerapatan dan penutupan jenis lamun diKepulauan Spermonde. Jurnal Torani. 22(3):156-162.

Hutomo, M. \& Nontji, A., 2014. Panduan Monitoring Padang Lamun. COREMAP - CTI Lembaga IImu Pengetahuan Indonesia. 37hlm

Kansil, Y., Khristin, I.F.K., Joudy, R.R.S., Alex, D.K., Adnan, S.W. \& Hermanto, M. 2019. Studi Morfometrik Lamun Thalassia hemprichii di desa Bahoi, Kabupaten Minahasa Utara. Jurnal Perikanan dan Kelautan Tropis, 10(3):102-109.

Kawaroe, M., Nugraha, AH., Juraij, I.A. \& Tasabaramo. 2016. Seagrass biodiversity at three marine ecoregions of Indonesia Sunda Shelf, Sulawesi Sea, and Banda Sea. Journal of Biological Diversity, 17(2):585-591.

Keputusan Menteri Lingkungan Hidup Nomor 51 Tahun 2004 tentang Baku Mutu Air. Jakarta: Sekretariat Negara. 
Metekohy, A.E. 2016. Strategi Pengelolaan Ekosistem Lamun Di Perairan Pantai Kampung Holtekamp Distrik Muara Tami Kota Jayapura Provinsi Papua. The Journal of Fisheries Development, 3(1):1-10.

Nasution, S. \& Siska, M. 2012. Kandungan logam berat Timbal (Pb) pada sedimen dan siput Strombus canarium di Perairan Pantai Pulau Bintan. Jurnal IImu Lingkungan, 5(2):82-93.

Newmaster, A.F., Berg, K.J., Ragupathy, S., Palanisamy, M. \& Sambandan, K. 2011. Local Knowledge and Conservation of Seagrass in the Tamil Nadu State of India. Journal of Ethnobiology and Ethnomedicine. 7(1):p.37

Nybakken, J.W. 1992. Biologi Laut Suatu Pendekatan Ekologis. Penerbit PT. Gramedia Jakarta.

Poedjirahajoe. 2013. Tutupan Lamun dan Kondisi Ekosistemnya di Kawasan Pesisir Madasanger, Jelenga dan Maluk, Kabupaten Sumbawa Barat. Jurnal IImu dan Teknologi Kelautan Tropis. $5(1): 36-46$

Rizal, A.C., Yudi, N.I., Eddy, A. \& Lintang, P. 2017. Pendekatan status nutrien pada sedimen untuk mengukur struktur komunitas makrozoobentos di wilayah Muara Sungai dan Pesisir Pantai Rancabuaya, Kabupaten Garut. Jurnal Perikanan dan Kelautan, 7(2):7-16

Rizkifar, M.A, Ihsan, Y.N., Hamdani, H. \& Sunarto. 2019. Jurnal perikanan dan kelautan, 10(1):7483

Rugebregt, M.J. 2015. Ekosistem lamun di kawsan pesisir kecamatan Kei Besar Selatan, kabupaten Maluku Tenggara, Provinsi Maluku, Indonesia. Jurnal Widyariset, 1(1):79-86

Sakey W.F, Wagey B.T. \& Gerung G.S. 2015 Morphometric Variation Of The Different Seagrass In Minahasa Peninsula Waters. Jurnal Pesisir Dan Laut Tropis. 1(1):1-7.

Sukandar, S. \& Dewi, C.S.U. 2017. Status lamun di Pulau Talango,Maduradan potensinya sebagai bahan baku bioaktif. Jurnal IImu-IImu perairan, Pesisir dan Perikanan. 6(2):138-144.

Susetiono. 2004. Fauna Padang Lamun Tanjung Merah Selat Lembe. Pusat Penelitian Oseanografi-LIPI. Jakarta

Triapriyasen, A., Muslim \& Suseno, H. 2016. Analysis of Types of Sediment Granules in the Waters of the Bay of Jakarta. Oceanographic Journal, 5 (3):309-316.

Tzeng, T.D., Chiu, C.S. \& Yeh, S.Y. 2000. Morphometric Variation in Redspot Prawn (Metapenaeopsis barbata) in Different Geographic Waters of Taiwan. Institute of Oceanography, National Taiwan University, Taipei 106, Taiwan ROC. Journal Fisheries Research, 53:211-217

Wagey, B.T. \& Sake, W. 2013. Variasi Morfometrik Beberapa Jenis Lamun Di Perairan Kelurahan Tongkaina Kecamatan Bunaken. Jurnal Pesisir Dan Laut Tropis. 1(3):36-44

Wangkanusa, M.S., Kondoy, K.I. \& Rondonuwu, A.B. 2017. Study on Density and morphometrics of seagrass Enhalus acoroides from Different Substrates on Coastal Waters of Tongkeina, City of Manado. Jurnal Ilmiah Platax. 5(2):210-220. 